\title{
NIEPOSŁUSZNA BIBLIOTEKA. „BIBLIOTEKA XX VEK” JAKO INSTYTUCJA KULTURY W SERBII OKRESU TRANSFORMACJI SYSTEMOWEJ
}

Słowa kluczowe: biblioteka, Serbia, instytucja kultury, Jugosfera, nieposłuszeństwo obywatelskie Keywords: library, Serbia, cultural institution, Yugosphere, civil disobedience

\section{DISOBEDIENT LIBRARY. „BIBLIOTEKA XX VEK” AS A CULTURAL INSTITUTION IN SERBIA DURING THE PERIOD OF SYSTEM TRANSFORMATION}

\section{S u m m a ry}

The text concerns scientific publishing series "Biblioteka XX vek", initiated in 1971 by Ivan Colović, Serbian anthropologist and publicist. During 50 years it has become an important cultural institution, which, due to its commitment to the current political and ideological affairs, gained a special role during the breakup of socialist Yugoslavia and then in terms of system transformation. In the 1990s it was an independent platform for the exchange of ideas, an ideological alternative to the nationalist regime, space for its deconstruction and criticism. "Biblioteka XX vek" takes part in animating intellectual Yugosphere - it consolidates the society of authors from former Yugoslav countries around such topics as: the memory of communism, Europeanisation of the Balkans, course and consequences of the transformation. The series paved the way for modern humanistic thought and modern scientific discourse in Serbia as well as supported these processes also in the ex-Yugoslav countries.

\section{Wobec librocydu}

Rozpad socjalistycznej Jugosławii w latach 90. w potocznej świadomości, ukształtowanej przez massmedia, kojarzony jest przede wszystkim z działaniami wojennymi, czystkami etnicznymi, spustoszeniem historycznych miast (Sarajewa, Dubrownika, Vukovaru i in.), wysiedleniami, eskalacją konfliktów zbrojnych i sporów ideologiczno-politycznych, z problematycznymi kompromisami i porozumieniami zawieranymi pod presją dramatycznych wydarzeń i kuratelą organizacji międzynarodowych i zachodnich decydentów. Ale rozpad południowosłowiańskiej 
federacji oznaczał także demontaż wieloetnicznego, wielojęzycznego i wielokulturowego środowiska intelektualnego, destrukcję wspólnej przestrzeni wiedzy, pewnego integralnego ekosystemu instytucji naukowych, fragmentację naukowej infrastruktury.

Jednym z przejawów tego procesu stał się librocyd (ang. libricide) - motywowane ideologicznie niszczenie, a także etniczne czyszczenie bibliotek i księgozbiorów ${ }^{1}$. Symbolicznym exemplum tego zjawiska są losy sarajewskiego Instytutu Orientalistycznego, zniszczonego wraz z bezcennym księgozbiorem w toku wojny w maju 1992 roku, oraz Narodowej i Uniwersyteckiej Biblioteki Bośni i Hercegowiny (Vijećnica), którą w sierpniu tego samego roku ostrzelała Armia Republiki Serbskiej. W ciągu paru dni zabytkowe budynki zostały obrócone w ruinę, bezcenne biblioteczne i archiwalne zbiory w zdecydowanej większości spłonęły, a wraz z nimi w imię politycznej racji jednego narodu bezpowrotnie została naruszona pamięć wieloetnicznego i wielowyznaniowego miasta i kraju - cywilizacyjny kod, „kulturowe DNA” wielonarodowej historycznej wspólnoty. Nieodwracalność tego aktu destrukcji przejmująco opisują słowa Dževada Karahasana, który pochylając się nad ruinami Instytutu Orientalnego, widzi „śmierć, która nie jest przejściem w inną formę istnienia, lecz odejściem w dosłowną, najdosłowniejszą nicość"2.

Polityke partykularyzacji i puryfikacji dziedzictwa narodowego realizowali w latach 90. nie tylko nacjonalistycznie zorientowani przywódcy państw powstających na gruzach SFRJ, lecz także liczni przedstawiciele elit intelektualnych i artystycznych oraz reprezentowane przez nich instytucje. Głos i autorytet uczonych (w tym także literatów, którzy zbyt mocno utożsamiali się z tworzoną przez siebie fikcją) stawał się najskuteczniejszą legitymizacją nowych (pseudo-)porządków, w których pod maską deklarowanych klasycznych wartości prawdy, piękna i dobra, coraz wyraźniej dochodziły do głosu kultura kłamstwa, kicz-wrażliwość oraz etyka wojny i wykluczenia ${ }^{3}$. Owi koryfeusze czystej, monologicznej pamięci realizowali równolegle politykę wymazywania i zapominania tego, co mogłoby naruszyć integralność i ciągłość wyznawanej przez nich narodowej monokultury. Jak zauważa Dubravka Ugrešić, celem takiej puryfikacji kolektywnej pamięci było to, by kłamstwo z czasem zostało zalegalizowane i uznane za nieweryfikowalną, a co za tym idzie niepodważalną prawdę ${ }^{4}$.

${ }^{1}$ Na temat librocydu vide Rebecca Knuth, Libricide: The Regime-Sponsored Destruction of Books and Libraries in the Twentieth Century (Westport \& London: Praeger Publishers, 2008); Ante Lešaja, Knjigocid. Uništavanje knjige u Hrvatskoj 1990-ih (Zagreb: Profil knjiga, 2012).

${ }^{2}$ Dževad Karahasan, „Razvalinski pejzaž kao vrt”, in idem, Knjigavrtova (Sarajevo: Connectum, 2004), 193. Cytat w przekładzie autorki niniejszego artykułu.

${ }^{3}$ Określenie kultura kłamstwa pochodzi z esejów Dubravki Ugrešić, Kultura laži. Antipolitički eseji (Zagreb: Biblioteka Bastard 1999), 81-100.

${ }^{4}$ Ibidem, 85-88. 
Układem odniesienia dla rozważań chorwackiej eseistki jest konkretny moment w historii - wojna oraz proces rozpadu jugosłowiańskiego państwa w latach 90. XX wieku - niemniej zadziwiająco aktualnie brzmiąca diagnozę i opis kultury kłamstwa można uznać za zapowiedź współczesnej kultury postprawdy - zdominowanej przez populistyczny przekaz, oparty na manipulacji opinią publiczną za pomocą informacji, w której kluczową rolę odgrywają emocje, a nie fakty. Nieprzypadkowo współczesnej ekspansji kultury postprawdy towarzyszy kryzys czytelnictwa. Czytanie jest bowiem praktyką wymagającą odpowiedniego przygotowania i zaangażowania intelektualnego, odwołującą się do cnoty rozumności i zmysłu krytycyzmu. Pod tym względem lektura zawsze niosła w sobie potencjał subwersji. Potwierdzenia tezy o wywrotowej sile książek i czytania dostarczają dzieje cenzury oraz niezliczone historyczne przykłady palenia ksiąg i prześladowania ich autorów. Jeśli zatem fascynuje nas opowieść o bibliotece, jaką w powieści Imię róży utrwalił Umberto Eco, to właśnie ze względu na fakt, że będąc synonimem ładu, rygorystycznie skonstruowanej struktury, okazuje się ona zarazem - jako depozyt wiedzy także tej zakazanej, kontestatorskiej, obrazoburczej - zagrożeniem dla ustalonego porządku, zarzewiem nieposłuszeństwa, inkubatorem herezji.

\section{Biblioteka idei}

O tym, że biblioteka (księgozbiór) może stać się przestrzenią oporu, platformą ideologicznego fermentu, medium niebezpiecznym dla idei, dowodnie przekonuje działalność wydawnicza serbskiego antropologa, Ivana Čolovicia, której ucieleśnieniem jest seria „Biblioteka XX vek”, dziś licząca już przeszło 230 tytułów. Założona w 1971 roku pod patronatem belgradzkiego Uniwersytetu Ludowego im. Braci Stamenkoviciów (Narodni univerzitet „Braća Stamenković”) przez ponad 40 lat istnienia stała się jedyną w swoim rodzaju - najpierw na gruncie jugosłowiańskim, a następnie postjugosłowiańskim — kroniką idei humanistycznych drugiej połowy XX i początku XXI wieku.

O szczególnej wartości tej edycji decyduje nie tylko zakres geograficzny i różnorodność tematyczna tworzących ją publikacji antropologicznych, kulturoznawczych, socjo- i politologicznych, lecz także sposób jej funkcjonowania jako niezależnej instytucji kultury. W odróżnieniu od innych przedsięwzięć z zakresu edytorstwa naukowego przetrwała ona rozpad socjalistycznej Jugosławii, zapaść wywołaną wojną i międzynarodowymi sankcjami, a także dramatycznymi perturbacjami na scenie politycznej, które w negatywny sposób zaważyły na przebiegu transformacji systemowej w Serbii. Będąc wyrazem zaangażowania jej twórcy w budowanie demokratycznej kultury publicznej, zarówno w czasach socjalistycznej Jugosławii, jak i w okresie rządów Slobodana Miloševicia, seria chwytała 
puls zdarzeń politycznych i procesów społecznych w kraju. By zrozumieć zasady jej funkcjonowania i znaczenie na przełomie XX i XXI wieku, należy także uwzględnić głęboki kryzys instytucjonalnych podstaw lokalnej kultury wiedzy. Wzorowana na serii „Bibliothèque des Idées”, wydawanej przez niezależną francuską oficynę Gallimard, „Biblioteka XX vek”, ogólnie rzecz ujmując, nawiązuje w sposób twórczy, ale też krytyczny do oświeceniowej linii europejskiej humanistyki, co wynika nie tylko z predylekcji intelektualnych wydawcy, lecz jest także reakcją na dominujące w serbskiej/jugosłowiańskiej myśli kulturowej nachylenie ku tradycjom romantyzmu oraz ideologicznym przekonaniom o narodowoodrodzeniowej genealogii. Jest rzeczą znamienną, że pierwszą opublikowaną przez Čolovicia książką był przekład pracy Paula Lengranda: Introduction à l'éducation permanente poświęconej kształceniu ustawicznemu ${ }^{5}$. Ta decyzja wynikała bezpośrednio z koncepcji realizowanej przez UNESCO, z której belgradzką agendą współpracował wówczas wydawca i w orbicie oddziaływań którego funkcjonował Uniwersytet im. Braci Stamenkoviciów. Ideową oś propagowanych przez tę organizację projektów reformy oświaty stanowił postulat samokształcenia człowieka przez całe życie, koncepcja samorealizacji opartej na holistycznym rozwoju (umysłowym, etycznym i estetycznym) i świadomym uspołecznianiu swej egzystencji, czego instytucjonalnym ucieleśnieniem miały stać się uniwersytety ludowe. Publikacja ta, podobnie jak i przekłady prac Charlesa P. Snowa The two Cultures and A Second Look, George'a Pickeringa The Challenge to Education i Bogdana Suchodolskiego Trzy pedagogiki ${ }^{6}$, realizowała zatem założenia programowe placówki, która była jej instytucjonalną ramą. Oznaczała również intensywniejsze włączenie się jugosłowiańskiej humanistyki w europejski nurt nowoczesnej refleksji dotyczącej aktualnych procesów społecznych. Określiła także kierunek polityki wydawniczej autora serii. „Biblioteka XX vek”, miała dostarczać narzędzi owej (obywatelskiej) paidei, rozumianej jako planowe i rozumne formowanie człowieka, dostosowanej jednocześnie do dynamicznie zmieniających się wymogów i ograniczeń cywilizacyjnych, a także do umysłowej konstytucji i wrażliwości człowieka drugiej połowy XX wieku.

Z czasem o profilu „Biblioteki XX vek” i szerokim rezonansie wśród czytelników zadecydowało intelektualne zaangażowanie w kluczowe problemy regionu i państwa. Polega ono na formowaniu nowego pola dyskursywnego osadzonego w transterytorialnej i interdyscyplinarnej przestrzeni intelektualnej, otwartego na nowy język adekwatny do opisu aktualnej rzeczywistości w jej wymiarze

\footnotetext{
${ }^{5}$ Pol Langran, Uvod u permanentno obrazovanje, trans. Vlatka Culek (Beograd: Biblioteka XX vek, 1971).

${ }^{6}$ Čarls Sinou, Dve kulture, trans. Aleksandar I. Spasić (Beograd: Biblioteka XX vek, 1971); Džordž Pikering, Izazov obrazovanju, trans. Jovan Dimitrijević (Beograd: Biblioteka XX vek, 1971); Bogdan Suhodolski, Tri pedagogije, trans. Miroslava i Radoslav Đokić (Beograd: Biblioteka XX vek, 1974).
} 
lokalnym oraz szerszych kontekstach interpretacyjnych, przede wszystkim europejskim. Takie umiejscowienie praktyki wydawniczej, uwzględniające czy też nawet konfrontujące spojrzenie wewnętrzne $\mathrm{z}$ perspektywą zewnętrzną, wydawało się zgodne ze zwrotnym charakterem podejścia poznawczego Colovicia jako antropologa ${ }^{7}$. Pozwalało zbudować dystans, będący warunkiem przemyślenia na nowo konstytucji zamieszkiwanej przez Serbów kultury (serbskiej, ale też jugosłowiańskiej i/lub bałkańskiej, ale też europejskiej). Sprzyjało również przewartościowywaniu obowiązujących paradygmatów teoretycznych i światopoglądowych. Co więcej, omawiana seria w tym przełomowym okresie sama w sobie stała się katalizatorem i nośnikiem przeobrażeń zachodzących w obszarze wzorów, postaw i praktyk społecznych. Uczestniczyła w rewizjach zbiorowych projektów tożsamościowych i poglądów na współczesność, a także - co bardzo istotne - sposobów rozumienia polityczności, już nie jako prostej identyfikacji ideologicznej czy przynależności partyjnej, lecz jako formuły świadomego i odpowiedzialnego bycia w świecie i społeczeństwie.

\section{YU-biblioteka}

W interesującym nas okresie transformacji systemowej, czyli od lat 90. ubiegłego stulecia, Colović opublikował szereg prac autorów serbskich i przekładów badaczy zagranicznych, które złożyły się na autorską propozycję - zalecanej (by nie powiedzieć obowiązkowej), chociaż niezadekretowanej w żadnym programie nauczania - antologii tekstów z zakresu antropologii politycznej. W serii można wyróżnić kilka bloków tematycznych, z których najsilniej reprezentowane są:

- nurt refleksji na temat rozpadu bloku państw komunistycznych, postkomunizmu oraz przebiegu transformacji w państwach bałkańskich oraz w Europie Środkowo-Wschodniej (m.in. Teofil Pančić, Urbani Bušmani. Život i smrt u srpskom postkomunizmu, 2001; Marija Todorova, Dizanje prošlosti u vazduh, 2010);

- problematyka dotycząca serbskiego nacjonalizmu oraz świadomości historyczno-kulturowej (m.in. Dušan Bandić, Carstvo zemaljsko i carstvo nebesko, 1997; Miodrag Popović, Vidovdan i časni krst, 1998; Ivan Čolović, Smrt na Kosovu Polju, 2016);

- zagadnienie kondycji i perspektyw społeczeństwa obywatelskiego w Serbii oraz - szerzej - w krajach postjugosłowiańskich (m.in. Mikloš Biro, Homo postkommunisticus, 2006; Ildiko Erdei, Antropologija potrošnje, 2008);

${ }^{7}$ Jedną z książek wydanych w serii jest Wyobraźnia antropologiczna Andrzeja Mencwela, którą w odniesieniu do całości projektu Čolovicia można czytać jako komentarz przyjętej przez niego strategii doboru tekstów (Antropološka imaginacija, trans. Ivana Đokić Saunderson i Jelena Jović (Beograd: Biblioteka XX vek, 2013)). 
- temat wojny i jej ideologicznych umotywowań, problem „niedokończonego” rozpadu Jugosławii oraz społecznej psychodynamiki jugonostalgii (m.in. Ivan Čolović, Bordel ratnika. Folklor, politika i rat, 1993; Vjekoslav Perica, Balkanski idoli. Religija i nacionalizam u jugoslovenskim državama, 2006; Mitja Velikonja, Titostalgija, 2010);

- namysł nad źródłami dyskursu bałkanistycznego i fenomenem bałkanizacji (m.in. Marija Todorova, Imaginarni Balkan, 1999; Božidar Jezernik, Divlja Evropa, 2007);

- krąg problemów związanych z procesami europeizacji oraz miejscem europejskiego komponentu kulturowego w postjugosłowiańskim uniwersum (m.in. Mitija Velikonja, Evroza, 2007; Ranko Bugarski, Evropa u jeziku, 2009).

W serii systematycznie swe miejsce znajdują również opracowania ogólne i teoretyczne, przede wszystkim tłumaczenia uznanych monografii z zakresu etnologii, antropologii kulturowej, filozofii kultury i antropologii polityki autorstwa zagranicznych badaczy, takich jak: Claude Lévi-Strauss, Mary Douglas, Alain Finkielkraut, Jean Cuisenier, Clifford Geertz, Anthony Giddens, Georges Balandier, Arjun Appadurai, Marc Augé, Slavoj Žižek ${ }^{8}$. Bez wątpienia zaprojektowana w ten sposób i z tak dużym rozmachem działalność przekładowa czyni $\mathrm{z}$ „Biblioteki XX vek” osobne w skali całego regionu narzędzie transferu idei, wymiany myśli i dokonań naukowych. W programie wydawniczym Čolovicia ujawnia się głęboki zamysł, by stworzona przez niego seria stanowiła autorską (a więc precyzyjnie wskazującą adres odpowiedzialności) i samoorganizującą się instytucję wytwarzania i kultywowania wiedzy, usytuowaną na obrzeżach obszarów nauki i edukacji zagospodarowanych i kontrolowanych przez (dysfunkcyjne) państwo. Bez wątpienia podziw budzi tematyczny i geograficzny zasięg wydawniczego przedsięwzięcia animowanego w zasadzie przez jednego człowieka. Jednak tym, co najbardziej waży na wartości edycji, wydaje się zdolność integracji pewnego środowiska intelektualnego, które należałoby określić jako nomadyczne - czyli otwarte i dążące do przekraczania ustalonych granic geograficznych, naukowych oraz ideowych. Jego wyróżnikiem jest przekonanie o utopijności esencjalistycznych koncepcji tożsamości, kwestionowanie zasadności jednoznacznej kulturowej, etnicznej czy narodowej identyfikacji w zdecentralizowanym, metamorficznym, płynnym świecie, sprzeciw wobec hegemonii jednej perspektywy, jednej ideologii, jednego dyskursu, jednego stylu. Čolović zaprasza do współpracy tych autorów, którzy opowiadają się za modelem wiedzy pozostającej w ruchu, dopuszczającej wielość punktów widzenia oraz interpretacji, a także umożliwiającej ich dekonstrukcję.

${ }^{8}$ Pełny spis książek opublikowanych w serii: http://www.bibliotekaxxvek.com/sve-knjige/ (acc. 29.05.2017). 
Trzon grupy współtworzącej mocą swych dzieł edycję stanowią autorzy z krajów dawnej Jugosławii. Obok mieszkających w Serbii Čolovicia, Teofila Pančicia, Ildiko Erdei, Mikloša Biro są to np. związani ze słoweńskimi ośrodkami naukowymi: Svetlana Slapšak, Božidar Jezernik i Mitja Velikonja, a także kojarzeni z Chorwacją Dunja Rihtman Auguštin, Miljenko Jergović, Vjekoslav Perica i Srećko Horvat. Twórcy ci w trudnym okresie transformacji systemowej, pozycjonując siebie i własne dokonania w zrekonfigurowanych układach geograficznych, politycznych, symbolicznych, a także światopoglądowych zdecydowanie opowiedzieli się za formułą krytycznego działania wewnątrz zdemontowanej pojugosłowiańskiej przestrzeni wiedzy. Joanna Kurczewska widzi w tym zamyśle Ivana Čolovicia gest „twórczej lojalności” wobec lokalnych tradycji „społecznie wrażliwej humanistyki" i konsekwentne dążenie do uczynienia jej liczącym się segmentem europejskiego życia intelektualnego9. Stąd też „Biblioteka XX vek”, budując intelektualną jugosferę $e^{10}$, czyli nieformalną i dynamiczną sieć autorów: uczonych i publicystów z regionu, staje się - wbrew logice rozpadu, na przekór politycznym podziałom, rozpodobnieniom, a także stagnacji i defetyzmowi - platformą polilogu, laboratorium krytycyzmu i rozumienia. Funkcjonuje w świadomości czytelniczej jako figura intelektualnego oraz ideowego oporu, dla którego zasadniczym, niejako naturalnym układem odniesienia pozostaje region Bałkanów w jego historycznych, cywilizacyjnych i politycznych uwikłaniach.

\section{Biblioteka na wojnie}

Aby zrozumieć miejsce, jakie „Biblioteka XX vek” zajęła w procesie formowania się pojugosłowiańskiej Serbii, należy przypomnieć najistotniejsze momenty jej politycznej biografii z tego okresu. Pełną, szeroko skontekstualizowaną rekonstrukcję losów wydawnictwa odnajdziemy w monograficznym opracowaniu

${ }^{9}$ Joanna Kurczewska, „Opinia dla Senatu Uniwersytetu Warszawskiego w związku z nadaniem tytułu doktora honoris causa Profesorowi Ivanovi Čoloviciowi”, in Uroczystość wręczenia doktora honoris causa Uniwersytetu Warszawskiego Profesorowi Ivanovi Čoloviciowi (Warszawa: Uniwersytet Warszawski, 7.05.2010), 5.

${ }^{10}$ Pojęcie Jugosfery wprowadził Tim Judah w odniesieniu do trwałej sieci relacji gospodarczych między krajami dawnej Jugosławii. Pytaniem otwartym pozostaje kwestia, czy czynnikiem integrującym jest tu wyłącznie interes ekonomiczny, a na ile można tu mówić o wspólnocie pamięci oraz swoistej interkulturze. Popularność pojęcia Jugosfery często budzi wśród publicystów krajów pojugosłowiańskich strach przed „reinkarnacją” Jugosławii. Jednakże w przypadku „Biblioteki XX vek” nie chodzi o stymulowane nostalgią kreowanie fantomowej struktury, lecz o animacje ,jugosłowiańskiej przestrzeni kulturalnej” (określenie Čolovicia) i zorientowaną naukowo, edukacyjnie i popularyzatorsko praktykę komunikacyjną w sferze funkcjonowania języków, które wyłoniły się z zadekretowanego w socjalistycznej Jugosławii języka serbsko-chorwackiego. Cf. Dubravka Stojanović, Noga u vratima. Prilozi za političku biografiju Biblioteke XX vek (Beograd: Biblioteka XX vek, 2011), 180. 
Dubravki Stojanović Noga u vratima. Prilozi za političku biografiju Biblioteke $X X$ vek. Niemal od początku swego istnienia seria wywoływała kontrowersje, a spór, jaki rozgorzał w wokół zbioru tekstów Dobricy Ćosicia Moć $i$ strepnje (1971), odczytanych jako krytyka ówczesnych posunięć Josipa Broza Tity, spowodował, że Uniwersytet Ludowy im. Braci Stamenković, bez mała w aurze skandalu, odstąpił od firmowania przedsięwzięcia swym autorytetem ${ }^{11}$.

Jednakże prawdziwą próbą niezależności stały się dla Čolovicia lata 90. ubiegłego stulecia. W 1989 roku „Biblioteka” została przekształcona w prywatne przedsięwzięcie, między innymi dlatego, że kryzys, będący następstwem zapaści gospodarczej kraju na skutek międzynarodowych sankcji wywołanych wojną, a następnie restrukturyzacja ekonomiczna sektora wydawniczego spowodowały, że kontynuacja współpracy z wiodącą państwową oficyną Prosveta, która od 1980 roku stanowiła instytucjonalne oparcie dla serii, okazała się niemożliwa (także z uwagi na pogłębiający się rozdźwięk między wizją i planami Čolovicia a polityką wydawniczą dotychczasowego mocodawcy). W związku z tym od 1989 roku zaczęła funkcjonować jako przedsięwzięcie prywatne, co pozwoliło jej zyskać większą niż dotychczas autonomię, było też wyrazem strukturalnej dystynkcji, która w krytycznych momentach uwydatniała opozycyjny charakter tej instytucji. Jednocześnie w warunkach chaotycznej, przybierającej postać stanu wojennego, transformacji ustrojowej, której przejawem była między innymi reorganizacja, a często też deprofesjonalizacja sektora drukarskiego i rynku wydawniczego, pojawiły się nowe problemy związane z finansowaniem i dystrybucją publikacji ${ }^{12}$. W tej sytuacji „Bibliotekę XX vek” wsparł Instytut Społeczeństwa Otwartego George'a Sorosa. Przedstawicielstwo tej instytucji rozpoczęło działalność w Belgradzie w 1991 roku, stając się w okresie międzynarodowych sankcji nałożonych na Serbię, jedynym źródłem finansowania pozarządowego sektora życia naukowego i kulturalnego, a także patronem antywojennych inicjatyw ${ }^{13}$.

Prawdziwym wyzwaniem dla redaktora i współpracowników wydawnictwa stała się ideologiczna radykalizacja elit politycznych w kraju, która spowodowała, że nacjonalizm szybko zyskał prymat w państwowej ,polityce symboli” oraz stał się normatywną treścią zbiorowego scenariusza oraz kołem zamachowym demontażu federacji. W tej sytuacji Čolović zajął otwarcie antywojenne i antyreżimowe stanowisko. Podczas wojny toczącej się na terytorium Bośni i Hercegowiny oraz Chorwacji podjął współpracę z niezależnym czasopismem „Republika”, kierowanym przez socjologa i działacza na rzecz społeczeństwa obywatelskiego, Nebojšę Popova, Niezależnym Stowarzyszeniem Intelektualistów „Belgradzki Krąg” („Beogradski krug”) oraz Centrum Akcji Antywojennych (Centar za

\footnotetext{
${ }^{11}$ Dubravka Stojanović, op. cit., 13-34.

12 Ibidem, 119.

${ }^{13}$ Ibidem, 129.
} 
antiratne akcije). W ramach aktywności tego opozycyjnego środowiska zaangażowanych intelektualistów - z jednej strony zepchniętego na margines życia publicznego w kraju, z drugiej zaś cieszącego się poparciem za granicą - została wypracowana koncepcja „drugiej Serbii”. Była to wizja alternatywna do tej, którą forsował oficjalny propagandowy przekaz w państwowych mediach. Ucieleśniała ideę demokratycznego, otwartego, nowoczesnego, a przede wszystkim odpowiedzialnego społeczeństwa ${ }^{14}$. Była wyrazem niezgody na fundamentalizm, quasi-religijny kult czystej etnicznie nacji, patologie pseudo-patriotycznych projektów i cynizm ich eksponentów (polityków, uczonych, artystów). Oznaczała sprzeciw wobec przemocy symbolicznej, którą posługiwano się dla legitymizacji nowych porządków, wobec „terroru” nacjonalistycznej wykładni kultury ${ }^{15}$, pozostającej na usługach autorytarnego reżimu. W pierwszym rzędzie jednak stanowiła protest przeciw kapitulacji i zniewoleniu rozumu.

W okresie wojny i pierwszej fazy transformacji ustrojowej (1989-2000) „Biblioteka XX vek" wzbogaciła się aż o 49 tytułów. Znamiennym, choć w pełni zrozumiałym faktem stała się zwiększona reprezentacja autorów z newralgicznego obszaru postjugosłowiańskiego. To w tym czasie do edycji dołączyli Słoweńcy Slavoj Žižek, Rastko Močnik oraz Dubravko Škiljan i Dunja Rihtman Auguštin z Chorwacji. Wówczas także, o czym przypomina Stojanović, „Biblioteka” zaczęła intensywnie eksplorować obszar antropologii politycznej, co było naturalną konsekwencją zdecydowanego wzmocnienia aktywistycznej postawy redaktora serii zarówno na gruncie prowadzonych przez niego badań, jak i w wymiarze działalności publicznej (popularnonaukowej i publicystycznej) ${ }^{16}$. Wyrazem tego zainteresowania były przekłady zagranicznych opracowań pióra Marca Abélès’a, Georges'a Balandiera, Raoula Girardet, a także publikacje autorskich prac Čolovicia Bordel ratnika. Folklor, politika i rat (1993) i Politika simbola. Ogledi o političkoj antropologii $(2000)^{17}$.

\section{Biblioteka oporu}

Zmiany demokratyczne wywołane reorganizacją politycznej sceny Serbii, czego kulminacją stała się tzw. rewolucja 5 października 2000 roku, kiedy to ostatecznie został obalony Slobodan Milošević, mimo spektakularnego przebiegu okazały się dość powierzchowne, a rewolucja - posłużmy się określeniem

\footnotetext{
${ }^{14}$ Ibidem, op. cit., 135-139.

${ }^{15}$ Cf. Ivan Colović, Bałkany - terror kultury, trans. Magdalena Petryńska (Wołowiec: Wydawnictwo Czarne, 2014).

${ }^{16}$ Cf. Dubravka Stojanović, op. cit., 145.

${ }^{17}$ Polskie wydanie: Ivan Čolović, Polityka symboli: eseje o antropologii politycznej, trans. Magdalena Petryńska (Kraków: Universitas, 2001).
} 
Andrzeja Ledera - „prześniona” ${ }^{18}$. System wypracowany w ciągu mijającej dekady wykazał się wyjątkową opornością zarówno na reformy instytucjonalne, jak i demontaż ideologicznej matrycy. Tragicznym dowodem na potwierdzenie tej tezy stało się w 2003 roku sterowane politycznie zabójstwo premiera Zorana Đinđicia, ucznia Jürgena Habermasa (podczas studiów filozoficznych w Niemczech), a przede wszystkim orędownika modernizacji i demokratyzacji Serbii. Przyczyną w istocie swej impotentnej obecności serbskiego października w świadomości społecznej Serbów była, jak się wydaje, nie tyle wizja przyszłości państwa, ile mitologizacja przeszłości (wraz ze stanowiącymi centrum tej narracji pamięcią bitwy na Kosowym Polu i etosem świętosawia ${ }^{19}$ ), która pozwalała widzieć Serbię w pozycji ofiary, ofiary wrogości sąsiadów (dziejowo motywowanej) i międzynarodowego spisku (istnienia którego ma koronnie dowodzić bombardowanie Serbii przez siły NATO w 1999 roku). Polityczną grę łatwiej jest rozgrywać odwołując się do rozpoznanej historii, interpretowanej w kluczu afirmacji retrospektywnie definiowanego narodu, nad którą można sprawować kontrolę, niż budując program konstruktywnego i progresywnego działania w obliczu niepewnej i mgławicowo rysującej się na horyzoncie przyszłości.

W reżyserowanej według tych pryncypiów rzeczywistości Čolović nadal wyznacza swojej „Bibliotece” miejsce na obrzeżach głównego, sterowanego „odgórnie" - z pozycji politycznych, życia publicznego. Dość przypomnieć pewien symptomatyczny moment „politycznej biografii” serii. Otóż od 2007 roku wydawca w geście krytyki obowiązującej formuły międzynarodowych targów książki w Belgradzie - na których preferowani są wydawcy komercyjni i koncerny medialne umacniające w ten sposób swą dominującą i monopolistyczną pozycję, natomiast marginalizuje się niskonakładowe, niezależne oficyny - postanowił zbojkotować imprezę oraz kulturalny establishment i zorganizować własną, alternatywną. Jej gospodarzem zostało belgradzkie Centrum Dekontaminacji Kulturowej (Centar za kulturnu dekontaminaciju) - jedna z najprężniejszych w Serbii organizacji pozarządowych, która za cel swej działalności przyjęła wytwarzanie oraz swobodną wymianę kultury i wiedzy na rzecz społecznej kohezji osiąganej z pomocą nieformalnych procedur demokratycznych ${ }^{20}$. Pierwszą edycję zainicjowanego przez Čolovicia „antysalonu” książki, który zachowując środowiskowy charakter, szybko zyskał międzynarodowy rezonans, otworzył znany

\footnotetext{
${ }^{18}$ Andrzej Leder, Prześniona rewolucja. Ćwiczenie z logiki historycznej (Wydawnictwo Krytyki Politycznej, 2014).

${ }^{19}$ Świętosawie - sformułowana w okresie międzywojnia idiomatyczna dla serbskiej świadomości kulturowej idea religijno-polityczna, łącząca tradycje związane z kultem świętego Sawy - twórcy autokefalicznej Serbskiej Cerkwi Prawosławnej - i wizję narodu opartą na zinstrumentalizowanej politycznie pamięci średniowiecznego państwa.

${ }^{20}$ Vide http://www.czkd.org/o-nama/ (acc. 29.05.2017).
} 
reżyser Dušan Makavejev, przedstawiciel niezależnego, poszukującego kina artystycznego $^{21}$. Po raz kolejny „Biblioteka XX vek” stała się impulsem twórczej, emancypującej zmiany.

\section{Lekcja nieposłuszeństwa}

Bez wątpienia działalność Ivana Čolovicia, której instytucjonalną artykulacją jest seria „Biblioteka XX vek”, można opisać za pomocą Habermasowskiej kategorii obywatelskiego nieposłuszeństwa, czyli bezprzemocowego, publicznego oporu wobec nadużyć państwa/władzy dokonywanych w świetle obowiązującego prawa. Oś tego rodzaju postawy stanowi etyczna zasada społecznej odpowiedzialności (a nie posłuszeństwa) jednostki za własne wybory i działania. Rozpatrywana w tej perspektywie inicjatywa serbskiego wydawcy okazuje się czymś więcej niż tylko swoistym ekosystemem dla myśli naukowej. Przyczynia się do nowego rozumienia historyczności i polityczności oraz - co w kontekście serbskim szczególnie ważne - reewaluacji praktyk oporu, mających bogatą tradycję, ugruntowaną na przełomie XX i XXI wieku. Čolović wpisuje się w ten jej nurt, który tworzy - posłużmy się określeniem Latinki Perović - „niechciana” elita, szukająca swego miejsca poza lokalnym mainstreamem inteligencji, świadoma jego ograniczeń i zobowiązań wobec władzy ${ }^{22}$. Postawa proaktywnego outsidera, którą Čolović od lat niestrudzenie realizuje w intelektualnej, autonomicznej i niezawisłej przestrzeni „Biblioteki XX vek”, współbrzmi z głosami innych autorów, które razem tworzą spójną, choć polifoniczną całość. Wyłania się z niej dyskursywny i złożony projekt nowej rzeczywistości społecznej, projekt zmiany, która ma się dokonywać mocą myśli, mocą tekstu.

\section{Bibliografia}

Čolović, Ivan. Bałkany - terror kultury, trans. Magdalena Petryńska. Wołowiec: Wydawnictwo Czarne, 2014.

Čolović, Ivan. Polityka symboli: eseje o antropologii politycznej, trans. Magdalena Petrýnska. Kraków: Universitas, 2001.

Karahasan, Dževad. Knjiga vrtova. Sarajevo: Connectum, 2004.

Knuth, Rebecca. Libricide: The Regime-Sponsored Destruction of Books and Libraries in the Twentieth Century. Westport \& London: Praeger Publishers, 2008.

${ }^{21}$ Vide Dubravka Stojanović, op. cit., 200.

${ }^{22}$ Latinka Perović, Dominantna i neželjena elita. Beleške o intelektualnoj i političkoj eliti u Srbiji (XX-XXI vek) (Beograd - Novi Sad: Dan Graf i Javna medijska ustanova „Radio-televizija Vojvodine", 2015). 
Kurczewska, Joanna. „Opinia dla Senatu Uniwersytetu Warszawskiego w związku z nadaniem tytułu doktora honoris causa Profesorowi Ivanovi Čoloviciowi”. In Uroczystość wręczenia doktora honoris causa Uniwersytetu Warszawskiego Profesorowi Ivanovi Človiciowi. Warszawa: Uniwersytet Warszawski, 7.05.2010.

Leder, Andrzej. Prześniona rewolucja. Ćwiczenie z logiki historycznej. Wydawnictwo Krytyki Politycznej, 2014.

Lešaja, Ante. Knjigocid. Uništavanje knjige u Hrvatskoj 1990-ih. Zagreb: Profil knjiga, 2012.

Mencwel, Andrzej. Wyobraźnia antropologiczna. Próby i studia. Warszawa: Wydawnictwo Uniwersytetu Warszawskiego, 2006.

Perović, Latinka. Dominantna i neželjena elita. Beleške o intelektualnoj i političkoj eliti u Srbiji (XX-XXI vek). Beograd - Novi Sad: Dan Graf i Javna medijska ustanova „Radio-televizija Vojvodine”, 2015.

Stojanović, Dubravka. Noga u vratima. Prilozi za političku biografiju Biblioteke XX vek. Beograd: Biblioteka XX vek, 2011.

Ugrešić, Dubravka. Kultura laži. Antipolitički eseji. Zagreb: Biblioteka Bastard 1999.

Strony internetowe:

http://www.bibliotekaxxvek.com/sve-knjige/ (acc. 29.05.2017).

www.czkd.org/o-nama/ (acc. 29.05.2017). 